\title{
Estudos da Interpretação em revista: história e modalidades de prática
}

\author{
Raffaella de Filippis Quental, Christiano Sanches do Valle Silva e \\ Denise de Vasconcelos Araujo*
}

Quando ficou decidido que um fascículo de Tradução em Revista seria especialmente dedicado aos Estudos da Interpretação (EI), não imaginávamos que seriam submetidos tantos artigos de interesse para a área e com qualidade para compor o volume. Foi, portanto, uma grata surpresa, ao nos envolvermos no processo de organização do número temático, chegarmos à conclusão de que seria possível, e desejável, dividir as contribuições em dois fascículos, cada um abordando subtemas específicos nesse vasto campo de estudos.

Assim, o volume 23, publicado no segundo semestre de 2017, dedicou-se a produções relacionadas mais claramente à pesquisa e formação de intérpretes. Neste segundo volume temático sobre Estudos da Interpretação, temos a satisfação de apresentar onze novas contribuições inéditas que, desta vez, abordam temas relacionados mais especificamente à história e às modalidades de interpretação em diferentes contextos. Os trabalhos selecionados compreendem duas traduções de autores estrangeiros consagrados, uma entrevista, três artigos abordando a interpretação em língua de sinais, dois tratando diretamente da formação de intérpretes e aspectos de sua história, um artigo sobre interpretação em tribunais, um sobre interpretação em contexto religioso e outro sobre a contribuição dos intérpretes negros na história do Brasil. Reunidos, todos enriquecem o cenário dos Estudos da Interpretação brasileiros, estabelecendo pontes com estudos em âmbito internacional e contribuindo

* Os organizadores são professores do Curso de Pós-graduação Lato sensu Formação de Intérpretes de Conferência da PUC-Rio, do qual Raffaella de F. Quental também é Coordenadora desde agosto de 2016. 
para firmar esse campo de pesquisas de maneira mais profunda em nosso território.

Abrindo o volume, Denise de Vasconcelos Araujo oferece, como um dos frutos de sua dissertação de mestrado, um panorama histórico do desenvolvimento da formação de intérpretes de conferência profissionais, concentrando-se, mais especificamente, na contribuição que a Associação Internacional de Intérpretes de Conferência (AIIC) trouxe para o campo, especialmente o estabelecimento de um padrão de melhores práticas.

Com um olhar mais direcionado, Raffaella de F. Quental nos brinda com uma necessária atualização do histórico de um dos cursos mais tradicionais de formação de intérpretes no Brasil, o da PUC do Rio de Janeiro. Conduzindo o leitor pela história do curso, Raffaella explicita as motivações que suscitaram mudanças de currículo e status do curso ao longo dos anos e através de diferentes cenários de política e mercado no país.

De caráter essencialmente historiográfico, o artigo de Dennys SilvaReis apresenta um esboço da história dos intérpretes negros no Brasil, reunindo elementos da tradição africana moderna, a concepção de intérprete no Império Português e a atividade de intérpretes negros no Brasil colônia e no Brasil império. Um importante documento que procura trazer à luz e compreender a identidade do intérprete negro na história do país.

De forma independente, porém complementar, a entrevista de Luciana Carvalho Fonseca com a intérprete Shanta Walker oferece um retrato atual do que é ser mulher e negra no contexto brasileiro da interpretação. Uma abordagem que reúne elementos de vivência pessoal com questões mais amplas de gênero e raça fundamentais para a compreensão da profissão e, mais ainda, para a compreensão das relações étnicas e de gênero na sociedade.

As duas traduções incluídas neste volume também se debruçam sobre elementos da história da interpretação. Marcelo Moreira foi o tradutor do artigo originalmente escrito por Alfred Hermann em alemão. Nele, é oferecido um panorama da atividade do intérprete na Antiguidade, 
abrangendo o Egito, a Grécia e a Roma antigos. Ao longo do texto, fica evidenciado o status dos intérpretes nessas três importantes civilizações.

Inserindo-se em um período histórico mais recente, Dennys SilvaReis e Marcos Bagno traduziram do francês o artigo de Jean Delisle sobre a atuação dos intérpretes franceses no Brasil do século XVI. Um relato rico em elementos de nossa história que também carrega em si informações que nos permitem entender a complexidade das relações tecidas com o uso da interpretação, seus limites e suas potencialidades.

Três artigos são dedicados à interpretação em língua de sinais. Maria Cristina Pereira apresenta uma sistematização das mais recentes publicações sobre interpretação em língua de sinais, num mapeamento de teses, dissertações e artigos que contribuem para dar forma e consistência a essa área específica de interesse. Diante de uma dualidade existente nos EI que ainda segrega línguas orais e de sinais, a autora propõe uma abordagem integradora que possibilite um conhecimento mais amplo das especificidades de cada modalidade e suas respectivas classificações.

Guilherme Lourenço dedica-se à observação e sistematização de aspectos morfossintáticos da interpretação simultânea Libras-português, usando tais elementos para explicar o processo de interpretação nesse par linguístico, focando especificamente em marcações de gênero, tempo e aspecto e questões relacionadas à sintaxe espacial da Libras. A partir dessa observação, são apresentadas estratégias para lidar com a atuação na direção sinais-para-voz.

Já Carlos Henrique Rodrigues e Silvana Aguiar dos Santos se debruçam sobre a atuação de intérpretes intermodais, de e para língua de sinais, refletindo sobre a singularidade de tais processos, a complexidade dos contextos de atuação e a importância da formação, com foco específico na atuação em serviços públicos.

Dois outros artigos abordam contextos de atuação específicos. Igor da Silva, Eliane Soares e Marileide Esqueda escolheram o contexto de uma igreja missionária evangélica no Brasil para estudar o processo interpretativo de intérpretes voluntários, gerando dados e observações sobre esse processo e sobre o perfil dos intérpretes num estudo exploratório. 
Finalmente, Reynaldo Pagura aborda a interpretação judicial (court interpreting) tal como ocorre nos Estados Unidos a partir do ponto de vista de alguém que atua no sistema. $\mathrm{O}$ autor identifica pontos de encontro entre a interpretação judicial e a interpretação de conferências, sugerindo que um mesmo intérprete seria capaz de atuar nas duas situações sem grandes dificuldades.

Como ficou claro após a leitura acima, este volume de Tradução em Revista reforça a noção de que os Estudos da Interpretação são, de fato, uma área de extrema riqueza e complexidade, oferecendo diferentes perspectivas de abordagem e estudo.

Mais uma vez, gostaríamos de reiterar nosso agradecimento à Comissão Editorial de Tradução em Revista, os Professores Marcia Martins, Maria Paula Frota e Paulo Henriques Britto, pela assistência contínua oferecida durante a organização deste volume. Conforme já mencionado no fascículo anterior, o espaço oferecido à área de Estudos da Interpretação no Brasil é muito oportuno para a formação de massa crítica numa área de estudos já bem estabelecida no exterior, porém ainda em franco desenvolvimento em nosso país. Agradecemos também a todos os autores que se sentiram motivados a compartilhar suas reflexões e pesquisas, bem como aos dezesseis pareceristas que contribuíram de forma indispensável para que os textos chegassem à revista com a qualidade esperada.

Desejamos uma boa leitura e esperamos que este número contribua para a disseminação das pesquisas na área de Estudos da Interpretação no Brasil, revelando sua diversidade e despertando o interesse dos pesquisadores no aprofundamento de temas tão pertinentes para a formação e o desenvolvimento profissional dos intérpretes. 